\title{
Becoming a Good Farmer-Becoming a Good Farm Worker: On Colonial Educational Policies in Germany and German South-West Africa, Circa 1890 to 1918
}

\author{
Jakob Zollmann
}

Notions of difference dominated contemporary German discourses about African colonies under German rule since 1885. Otherness and conceptual othering informed writing about Africans but also affected those Germans who decided to live in the colonies (German South-West Africa [GSWA, present-day Namibia], German East Africa [GEA, present-day Tanzania], Cameroon, and Togo). The requirements these men (and soon also women) had to fulfil, it was postulated, were different

The author expresses his gratitude to Dag Henrichsen and Herbert Lewis for their critical comments.

J. Zollmann $(\square)$

WZB Berlin Social Science Center, Berlin, Germany

e-mail: jakob.zollmann@wzb.eu

(C) The Author(s) 2020

109

D. Matasci et al. (eds.), Education and Development in Colonial

and Postcolonial Africa, Global Histories of Education, https://doi.org/10.1007/978-3-030-27801-4_5 
from what was necessary for a "successful" life in the metropole. In Germany, colonial pressure groups and the colonial administration were thus looking for the "ideal settler," who was in pursuit of better prospects than the overcrowded metropolis could offer. Yet the question for contemporaries was: What was to be expected from such an "ideal settler"? How should these men earn a living in Africa (or the few other German colonies on the Pacific Islands)? Agriculture was often seen as the most advisable and preferable undertaking for settlers. The reason for this was that it would allow men from all walks of life to develop their own homesteads, using their own two hands, in the "primitive" conditions of the colonies. But given the imaginary task to create not only a Neu-Deutschland, but a different, a "better Germany" overseas, free from the "vices of modernity," were those Germans arriving in the colonies prepared for their futures? ${ }^{1}$ How and where were they supposed to gain the knowledge needed for their colonial ventures? ${ }^{2}$ In short, questions of knowledge accumulation with regard to the colonies and "colonial education" for (future) economic actors were paramount to the entire German colonial project and the settlement schemes that served to justify associated public expense (on this issue, see Chapter 6 by Caterina Scalvedi and Chapter 7 by Michael A. Kozakowski, both in this book).

Taking the example of German South-West Africa and the education of (prospective) farmers for life in this colony, this chapter is an attempt to merge the sub-fields of German (colonial) agrarian history and the history of (colonial) education into one analytical field. Education, teaching, learning, and knowledge are elementary and interrelated terms of pedagogy, and the theory and practice of education, teaching, and learning by historical actors offers concrete insights into societal norms and historical ideas about the future. ${ }^{3}$ This is particularly relevant for contemporary debates about the German colonies and their intended

\footnotetext{
${ }^{1}$ Birte Kundrus, Moderne Imperialisten: Das Kaiserreich im Spiegel Seiner Kolonien (Cologne: Böhlau, 2003), 43.

${ }^{2}$ On questions of "colonial knowledge," see Rebekka Habermas and Alexandra Przyrembel, Von Käfern, Märkten und Menschen: Kolonialismus und Wissen in der Moderne (Göttingen: V\&R, 2013), 10.

${ }^{3}$ Theodor Schulze, "Erziehung und Lernen. Plädoyer für eine mathetische Erziehungswissenschaft," in Erziehungsdiskurse, ed. by Winfried Marotzki and Lothar Wigger (Bad Heilbrunn: Klinkhardt, 2008), 29-50, 37.
} 
futures. Colonial activities by law makers, administrators, and-last but not least-settler communities were not only meant to "initiate the beginning of state formation," 4 as argued in 1886 by the state secretary of justice Herrmann von Schelling; colonies were also meant to develop into future sources of national wealth. ${ }^{5}$

From the perspective of policy makers, colonial education, as one form of colonial activity by officials and missionaries, was thus a process that concerned both the colonizers and colonized in the colonies and the metropolis. Its aim was to contribute to an improved, economically viable future for the colonies (on this issue, see Chapter 1 of this book by Damiano Matasci). Typically, there was a generational aspect of transferring agrarian knowledge. In the case of agrarian knowledge to be applied successfully by settlers in the colonies, this generational aspect of knowledge transfer, however, differed from other educational efforts in schools and universities in the metropole. The knowledge about the colonies often had to be gained at almost the same time (during research excursions) as it was supposed to be already available for dissemination to future farmers and others in Germany and the colonies. Those teaching and those learning about the agricultural conditions in the colony understood that many questions remained unanswered for the time being. For many problems related to farming in the colonies, solutions still had to be found through continued research before being institutionally transformed into empirical knowledge and educational material. Further, farmers did not always accept as applicable research findings by academics. Complaints about the "amateurism [Laientum] of our farmers" in GSWA remained until the demise of the German colonial empire in $1914 .^{6}$

\footnotetext{
${ }^{4}$ Stenographische Berichte des Reichstags, 6. Leg. Per., 2. Session, 1885/1886, vol. 1, session of 20.1.1886, 653.

${ }^{5}$ See Jakob Zollmann, "'Neither the State Nor the Individual Goes to the Colony in Order to Make a Bad Business': State and Private Enterprise in the Making of Commercial Law in the German Colonies, ca. 1884 to 1914," in The Influence of Colonies on Commercial Law and Practice, ed. by Serge Dauchy and Albrecht Cordes (Leiden: Brill, 2020).
}

${ }^{6}$ Bundesarchiv Berlin (BAB) N 2272/1, Bl. 28-30, Heydebreck to Schuckmann, 9 February 1914. 
The necessity to contextualize knowledge and education is most evident $^{7}$ in the context of colonization. Therefore, this chapter will consider four points of interest: (1) how colonial enthusiasts and administrators perceived the necessity for improved tropical agricultural education given the setbacks farmers experienced in GSWA; (2) how knowledge related to tropical agriculture was institutionalized and administered; (3) how, in Germany, two schools for tropical agriculture were set up; and (4) how the debate on the "education" of the African workforce in GSWA contributed to the exclusion of this group from the most elementary forms of education.

\section{Conditions and Development Plans for Farming in GSWA-The Necessity for Agricultural Education}

In 1883-in German pre-colonial times-the Hamburg lawyer, tradesman, and self-stylized expert on Africa, Wilhelm Hübbe-Schleiden (18461916), defined "colonialization-policy and colonization-technique" as the "art of colonial culture work [colonisatorische Kulturarbeit]." "Extensive cultivation" of colonized territories was for him, in the interpretation of historian Dirk van Laak, "cultural education," because, as HübbeSchleiden argued: "Colonization in new territories is a repetition of our own cultural development." 8

In GSWA, such attempts at "repetition" and "cultural education"9 were hampered, however, by the main constraint faced by the agricultural sector - the lack of water. The territory "has the driest climate in Africa south of the Sahara" and thus "agricultural production has, for the most part, remained marginal." 10 Whereas, due to the growing urban markets in the region, neighboring South Africa, witnessed, in the words

\footnotetext{
${ }^{7}$ Carola Groppe, Im deutschen Kaiserreich: Eine Bildungsgeschichte des Bürgertums 18711918 (Vienna: Böhlau, 2018), 5.

${ }^{8}$ Dirk van Laak, Imperiale Infrastruktur: Deutsche Planungen für eine Erschließung Afrikas 1880-1960 (Paderborn: Schöningh, 2004), 62; quoting W. Hübbe-Schleiden, Colonisations-Politik und Colonisation-Technik (Hamburg, 1883), 3.

${ }^{9}$ On the colonial topos of the paternalistic "education" of "backward peoples," see Sebastian Conrad, Globalisierung und Nation im deutschen Kaiserreich (Munich: Beck, 2006), 55.

${ }^{10}$ Tony Emmett, Popular Resistance and the Roots of Nationalism in Namibia, 19151966 (Basel: Schlettwein, 1999), 39.
} 
of historian Colin Bundy, a "virtual 'explosion' of peasant activity in the 1870s," 11 the more arid regions to the north remained untouched by this "explosion." Whereas south of the Orange (Gariep) River, peasants increased their output of meat and wool production, breeding levels of ostrich and drought animals (oxen), dairy products, grain, fruit, and vegetables, the thinly populated Great Namaqualand, as it was contemporarily called, remained most famous for its hunting grounds for hides, ostrich feathers (which dwindled), and livestock breeding (i.e., small stock). Further north, in Hereroland, for example, cattle were bred and elephants were hunted for their ivory.

Bearing in mind such challenging environmental conditions, starting in the 1880s, German colonial enthusiasts still envisioned grandiose settlement schemes for GSWA. Their financial viability and feasibility in the face of the arid realities of the country remained, however, dubious. ${ }^{12}$ Given the extremely dry climate in GSWA, barely $1 \%$ of the territory was suitable for crop cultivation. However, at least large parts could be used for cattle, goat, and sheep breeding. ${ }^{13}$ From pre-colonial times, and until the outbreak of the war in 1904, the export of cattle from Hereroland (a grassland and bushland zone in the center of the later German colony) to the industrialized zones of the Cape and the mining districts of the Rand proved lucrative and remained an important economic factor for the territory. ${ }^{14} \mathrm{Up}$ to the 1890 s, the main export product remained, however, guano deposits from Cape Cross and other coastal areas-used mostly as a fertilizer in the wineries of the Cape region. Once deposits were depleted, hopes remained high that gold, copper, and other minerals would prove lucrative. However, apart from the copper mines of Otavi most of these plans came to nothing, with diamonds only being found in 1908. Promising investment options were thus limited and by the mid-1890s it became evident that very few individuals had come over

${ }^{11}$ Colin Bundy, The Rise and Fall of the South African Peasantry (London: Currey, 1979), 67.

${ }^{12}$ See Alvin Kienetz, Nineteenth-Century South West Africa as a German Settlement Colony (2 vols.), diss. phil. University of Minnesota, 1976.

${ }^{13}$ Markus Denzel, "Die wirtschaftliche Bilanz des deutschen Kolonialreiches," in Die Deutschen und ibre Kolonien. Ein Überblick, ed. by Horst Gründer and Hermann Hiery (Berlin: Bebra, 2017), 144-160, 148.

${ }^{14}$ Johann Rawlinson, The Meat Industry of Namibia, 1835-1994 (Windhoek: Gamsberg, 1994). 
from Germany, daring to invest their capital and labor in colonial land in order to raise cattle. The German colonial government tried to find some arable land and further territories suitable for extensive cattle farming by usurping land from the Africans. Yet, by the late 1890s, barely 1200 Germans lived in the colony, of which around 800 were soldiers or government officials. ${ }^{15}$ Thus, in GSWA "farmers" of European origin barely numbered in the hundreds-many of them were not Germans, but Afrikaners arriving from the Cape or Transvaal. ${ }^{16}$ This hesitation to settle in GSWA points to issues in the political economy of this colony that are in need of further explanation.

In the early days of formal German rule in GSWA, the indigenous population, mostly Ovaherero herders, continued to raise cattle successfully in order to amass wealth and status. "[F]rom the 1880s Herero were regarded as wealthy cattle-owners par excellence." ${ }^{17}$ It is said that the cattle herds of the most important ovahona (big men), such as Maharero and Kambazembi, numbered at times 40,000 or even 70,000. Given Herero knowledge of water sources and grazing areas, it was inconceivable that new arrivals from Germany would be able to compete with the African cattle breeders, let alone "outfarm black peasants" - to borrow an expression from Colin Bundy. ${ }^{18}$ The few who did try often failed miserably. They attempted to diversify their business into hunting and most of all itinerant trading in (European consumption) goods in exchange for cattle and hides. ${ }^{19}$

However, the economic and thus the political situation changed completely with the rinderpest epidemic of $1897 / 1898$. The dangers of animal diseases in southern Africa, especially for horses and oxen, had been described early on by European travelers and scientists. ${ }^{20}$ However, the

${ }^{15}$ Deutsche Kolonialgesellschaft, Kleiner Deutscher Kolonialatlas (Berlin: Reimer, 1899), remarks Map 5.

${ }^{16}$ Robbie Aitken, "Looking for Die Besten Boeren: The Normalisation of Afrikaner Settlement in German South West Africa, 1884-1914," Journal of Southern African Studies 33, no. 2 (2007): 343-360.

${ }^{17}$ Dag Henrichsen, Herrschaft und Alltag im vorkolonialen Zentralnamibia. Das Hereround Damaraland im 19. Jahrhundert (Basel: BAB, 2011), 186, translation in Marion Wallace, A History of Namibia (London, 2011), 104.

${ }^{18}$ Bundy, The Rise and Fall of the South African Peasantry, 67.

${ }^{19}$ Matthias Häussler, Der Genozid an den Herero (Weilerswist: Velbrück, 2018), 47.

${ }^{20}$ See Hans Schinz, "Ein neuer Bauernstaat im Südwesten Afrika's," Mitteilungen der Ostschweizerischen Geographisch-Commerciellen Gesellschaft in St. Gallen (1886), 26-31, 27. 
rinderpest had a hitherto unprecedented death toll. The German colonial army (Schutztruppe) helped to inoculate animals owned by German farmers or the government using a method developed on the spot by Robert Koch. About 80,000 cattle were rescued. ${ }^{21}$ Ovaherero, on the other hand, were much harder hit because they lacked the ability to vaccinate. At the same time, Governor Leutwein continued with his policy of land confiscation from Africans, trying to free grazing ground for prospective German farmers through "agreements" with Herero chiefs about "German" and "Herero" land. Given the unattainable knowledge of Ovaherero herders about the raising of cattle, Leutwein was intent on actively reducing their herds. He justified this measure by invoking the necessity to protect "our farmers" from the economic power of the Ovaherero (through their expanding cattle herds); otherwise he foresaw "difficult imbroglios." 22 During the epidemic, some Herero families lost up to $90 \%$ of their herds. These disastrous losses forced them to sell their remaining cattle as well as land to the Germans in order to repay their "debts" to German traders.

In this context, it is relevant to recall that "in pre-colonial societies the land was owned communally and could therefore not be inherited, private property existed mainly in the form of livestock, especially cattle, goats, sheep, horses, donkeys." 23 The notion of private, vendible land titles (including water wells) was thus foreign to Herero and other groups. And yet the German colonial government continued to press for strict limits between communal (African) land and private (German) land acquired from Africans-cattle that had "trespassed" into German farming areas were confiscated. The political goal behind this willingly accepted impoverishment of the Herero was twofold: first, the creation of large swathes of land "free" to be "developed" by German settlers eager to start their own farms; and second, the creation of a class of wage-dependent African farmworkers. As long as Herero chiefs

\footnotetext{
${ }^{21}$ Myron Echenberg, “'Scientific Gold': Robert Koch and Africa, 1883-1906," in Agency and Action in Colonial Africa, ed. by C.P. Youé and T.J. Stapleton (London: Palgrave, 2001), 34-49; Giorgio Miescher, "Namibia's Red Line," The History of a Veterinary and Settlement Border (New York: Palgrave, 2012), 29.

${ }^{22}$ Cited in Helmut Bley, Kolonialherrschaft und Sozialstruktur in Deutsch-Südwestafrika (Hamburg: Leibnitz, 1968), 75, 82-85.

${ }^{23}$ Ellen Ndeshi Namhila, "Little Research Value": African Estate Records and Colonial Gaps in a Post-colonial Archives (Basel: BAB, 2017), 59.
} 
controlled huge cattle herds and large territories, these German plans for a colonial future were impossible to attain. Therefore, the rinderpest epidemic was an important stepping stone toward the goal of a strong German farming community in GSWA. By 1902, Herero-owned cattle herds had diminished to about 46,000, down from about 100,000 in the early 1890s, and the number of cattle owned by Germans had risen to $44,000 .{ }^{24}$ It was thus no wonder that Germans in GSWA believed that "the outbreak [of the rinderpest] had a positive impact on economic development." 25

Given the hesitation of individual Germans to purchase land in GSWA, in the 1890s the German colonial administration resorted to selling concessions for large tracts of land in the colony to joint-stock companies - these were often financed by British money, which many in Germany deplored. ${ }^{26}$ Consequently, in 1903 six companies owned around $38 \%$ of the territory of GSWA. ${ }^{27}$ However, their land policies, aimed at selling farms to individual farmers, were poorly planned and executed. They barely served the overall aim of establishing a settler colony. The "first organized efforts to resettle Germans on the colonial frontier," having started in 1892, ended with a "string of failures and lawsuits and a dire tale of proletarianization." 28

Other areas remained "crown land," owned by the government. Yet despite a growing number of Germans in GSWA (3000 in 1903) the development of a farming economy did not take off. Former governor (Landeshauptmann) Curt von François stated that GSWA is not "what it is supposed to be, an export market for Germany." 29 Nor were German farmers in GSWA exporting their produce to Germany. Whereas by "the

\footnotetext{
${ }^{24}$ Wolfgang Werner, No One Will Become Rich: Economy and Society in the Herero Reserves in Namibia, 1915-1946 (Basel: Schlettwein, 1998), 44f.

${ }^{25}$ Miescher, Namibia's Red Line, 30.

${ }^{26}$ Friedrich Bruck, "Die Zukunft Deutsch-Südwestafrika," Die Grenzboten 1/1899 (59. Jg): 289-299; Curt von Francois, Staat oder Gesellschaft in unseren Kolonien (Berlin, 1901) (Soziale Streitfragen vol. X).

${ }^{27}$ Kundrus, Moderne Imperialisten, 47; see Horst Drechsler, Südwestafrika unter deutscher Kolonialherrschaft. Die großen Land- und Minengesellschaften, 1885-1914 (Stuttgart: Steiner, 1996).

${ }^{28}$ John Phillip Short, Magic Lantern Empire: Colonialism and Society in Germany (Ithaca, NY: Cornell University Press, 2012), 71.

${ }^{29}$ Curt von Francois, "Unsere südwestafrikanische Kolonie," Die Grenzboten 56, no. 4 (1897): 67.
} 
turn of the twentieth century, Britain's tropical African colonies had begun to undergo an 'export boom' in agricultural and mineral products, $" 30$ in 1899, a publication by the pressure group, German Colonial Society $(D K G)$, listed very few export products of GSWA: "hides, horns, ostrich feathers, natural resin, tanning substances, guano, raw furs." GSWA's exports amounted to barely 1.2 million Reichsmark. ${ }^{31}$ In fact, around 1900, most of the Europeans still lived "almost exclusively on the money ... that the military and officials bring into the [colony]," with most Germans in the colony working either directly or indirectly for the government. ${ }^{32}$ The privileged land allocations to big land companies were repeatedly met with criticism. ${ }^{33}$ With regard to German colonization, the geographer Friedrich Ratzel criticized, in his Introduction to Heimatkunde, that it had "benefitted only the freer activity of individuals or small groups, not the masses." 34

After 1900, it became increasingly clear to the colonial administration in Berlin that the old Bismarckian idea that private money exclusively should stir colonial development had failed. Government measures taken to promote the economy in the colonies were half-hearted. However, the 1901 imperial budget for GSWA listed not only planned expenses for new buildings, roads, and the expansion of the harbor in Swakopmund, but also investments in wells and dams and other activities that aimed to improve agriculture and stock farming. ${ }^{35}$ By engaging in such fiscal activity, the government aimed to respond to allegations that the colonial administrators had privileged land companies over ordinary settlers. ${ }^{36}$ Despite such efforts, by 1904 the number of farmers from Germany had barely risen to $300 .{ }^{37}$

${ }^{30}$ Helen Tilley, Africa as a Living Laboratory: Empire, Development, and the Problem of Scientific Knowledge, 1870-1950 (Chicago: University of Chicago Press, 2011), 124.

${ }^{31}$ Deutsche Kolonialgesellschaft, Kleiner Deutscher Kolonialatlas (Berlin: Reimer, 1899), remark Map 5.

${ }^{32}$ Francois, "Unsere südwestafrikanische Kolonie," 72.

${ }^{33}$ Friedrich Bruck, "Die Zukunft Deutsch-Südwestafrikas," Die Grenzboten 1, no. 59 (1899): 289-299, 298.

${ }^{34}$ Friedrich Ratzel, Deutschland: Einführung in die Heimatkunde (Leipzig: Grunow, 1898), 308.

${ }^{35}$ Reichsgesetzblatt (Berlin, 1901), 92.

${ }^{36}$ See Bley, Kolonialherrschaft, 110, 172.

${ }^{37}$ Berengar von Zastrow, "Farmwirtschaft," in Die deutschen Kolonien in Wort und Bild, ed. by Hans Zache (Berlin: Andermann, 1926), 163-169, 163. 
Government plans for the settlement of farmers did not guarantee success either, some ended in disaster for the individuals involvedoften former colonial soldiers. From the colonial government, they had received "crown land" very cheaply (3000-5000 hectares in the savanna areas in the central and northern part of GSWA, and up to 20,000 hectares in the arid south); but their business plans were underfinanced and many lacked specific knowledge and experience in agriculture. In addition, living conditions could worsen any time due to a lack of rain, transport, customers and thus turnover. An additional problem in this respect was a lack of workforce. In many cases relations between German farmers and their African workforces were characterized by poor payments, lack of food, and-at times-violence. ${ }^{38}$ Given these underlying difficulties, if diseases struck herds or crops, farmers became bankrupt. For example, the 33-year-old W. Bandelow, who had served with the colonial military, the Schutztruppe, from 1893 to 1899 and then settled as a farmer near Rehoboth, had, after "many setbacks, loss of property and cattle diseases," merely 1 horse, 6 cows, and 20 goats. In 1903 he wrote to the colonial administration: "Since I cannot get on with this, I beg... to get me a position as a policeman somewhere." 39

There were of course counterexamples of farmers having financial success due to their cattle sales. But in response to the difficulties that farmers complained about and given the overarching political goal to populate the colony with more German settlers in order to "make the country German," the government became more willing to grant loans for prospective farmers. Colonial administrators like the future governor Friedrich von Lindequist further developed plans to accelerate this population policy with the granting of smaller plots of farmland (a few hectares) to German settlers (Kleinsiedler) in the few parts of Hereroland where rain was more abundant, for example, near Okahandja or around the Waterberg. The Kleinsiedler were supposed to grow wheat, fruit, and vegetables for the few towns in the colony. Again, the experience and

${ }^{38}$ See Andreas Eckl, "Weiß oder Schwarz? Kolonialer Farmalltag in DeutschSüdwestafrika," in Die (koloniale) Begegnung: AfrikanerInnen in Deutschland und schwarze Deutsche, ed. by Marianne Bechhaus-Gerst and Reinhard Klein-Arendt (Frankfurt/M.: P. Lang, 2003), 109-124; Jakob Zollmann, Koloniale Herrschaft und ibre Grenzen: Die Kolonialpolizei in Deutsch-Südwestafrika (Göttingen: V\&R, 2010), 281-299.

${ }^{39}$ National Archives of Namibia (NAN) BWI 155, L 2 e, Bl.37, Protokoll W. Bandelow. DKdo Rehoboth, 9.1.1903; B1. 36, BHpt Windhoek to DKdo Rehoboth, 19.1.1903. 
knowledge of the Ovaherero was decisive here, since in the early 1890 s Herero farmers had already had some success growing wheat, corn, and tobacco. Cereal cropping was part of their economic strategy of diversifying their income in times of falling cattle prices. However, in absolute terms the quantity of cereals produced remained limited. ${ }^{40}$ It turned out that a colonial project like the Kleinsiedlungen (literally "small settlements"), aiming at the mise en valeur and the socioeconomic transformation of GSWA, could not transcend the bounds set by the climate and (colonial) economy. As horticulturalists, the German Kleinsiedler, as contemporary critics had warned, hardly had success in this attempt to meaningfully expand the production patterns of the colony. And even if they succeeded in their production, they had not enough customers in the vicinity to make their undertaking economically viable. ${ }^{41}$

If "cultural education" in the colony was the political goal, in an attempt to repeat the economic development of Germany, very little had been achieved. It was only in the aftermath of the wars against the Ovaherero and Nama (1904-1908) that the colonial administration started in earnest to implement its plans for a German farming community in the center of the colony. But even then, and despite statefunded subsidies for new farmers (around 500,000 Marks per year), "many farms, undercapitalised and in debt, were soon in a parlous economic state." 42 In Germany, the press ridiculed the "dream of settlement colonialism." 43

In modern academic parlance, these administrative policies can rightfully be described as "social engineering," 44 aimed at creating order, security, and economic viability in an agricultural zone that was still to be established in an environment perceived by the German settlers as dangerous and inimical. It turned out that Germans willing to work in GSWA had first to educate themselves about the conditions of its territories before attempts to develop the colony could be undertaken. The colonial government's increasing reliance on knowledge

\footnotetext{
${ }^{40}$ See Henrichsen, Herrschaft und Alltag im vorkolonialen Zentralnamibia, 184.

${ }^{41}$ Zastrow, "Farmwirtschaft," 165; see Kundrus, Moderne Imperialisten, 61-77.

${ }^{42}$ Wallace, A History of Namibia, 186.

${ }^{43}$ Short, Magic Lantern Empire, 71.

${ }^{44}$ See Carl Marklund, "Begriffsgeschicht and Übergriffsgeschichte in the History of Social Engineerung," in Die Ordnung der Moderne: Social Engineering im 20. Jabrhundert, ed. by Thomas Etzemüller (Bielefeld: transcript, 2009), 199-222, 199.
} 
about the colonies and "scientific" techniques to attain its goals grew out of the experiences of those having failed during the two decades following 1885 .

\section{Colonial Knowledge and Tropical Agriculture: A Research and Teaching Subject in Germany-An Administrative Task in GSWA}

Knowledge about humans, animals, plants, geology, etc., that was specific to the colonies had always played an important role in the upkeep of colonial rule by European overlords. Since the days of the Portuguese "explorers" (self-declared) academic specialists had accompanied colonial administrators. They observed, took notes, compared, and produced texts about their findings. They were asked to do so in order to enable colonial officials and their troops to penetrate ever deeper into hitherto unknown territories, which were in the long run to be transformed into economically viable colonies. To this end, in the British colonies throughout the eighteenth and nineteenth centuries a number of publications were written on "tropical" agricultural questions. ${ }^{45}$

By the late nineteenth century, the buildup of a corpus of knowledge about tropical agriculture, mostly acquired through the experiences of settlers in the colonies, was part of the general development toward the "scientification of the colonial" (Verwissenschaftlichung des Kolonialen). ${ }^{46}$ Near London, the botanical gardens at Kew collected plants from all over the globe. In Berlin, in 1891, the Botanische Zentralstelle für die deutschen Kolonien began to undertake research on the plants and seeds it received from the colonies. Government departments dedicated to agricultural services were set up in colonies around the world. Questions arose about the educational requirements of future staff at such departments. At the same time training, not only of (academic) specialists but also settlers eager to work in agriculture, was given greater attention by colonial administrators. In 1893, in Ceylon a "Superintendent of

\footnotetext{
${ }^{45}$ See George Porter, The Tropical Agriculturist: A Practical Treatise (London: Smith, 1833).

${ }^{46}$ Anne Kwaschik, Der Griff nach dem Weltwissen: Zur Genealogie von Area Studies im 19. und 20. Jahrhundert (Göttingen: V\&R, 2018), 29.
} 
the School of Agriculture" was appointed. In 1899, in Dominica in the Caribbean the title "agricultural instructor" was used for the first time. ${ }^{47}$

The establishment of institutions of tertiary education, specifically set up for men (and sometimes women) planning to work in the colonies, was on the agenda of colonial officials around 1900. British, French, German, Belgian, and Dutch administrations developed curricula, and Ph.D. and M.D. theses were written on "colonial subjects." Contemporaries were aware that such knowledge served as an "Instrument of Empire." 48 However, in the age of empire before World War I the "science of colonization" still had to prove, to contemporaries, its scientific character (Wissenschaftlichkeit). As historian Anne Kwaschik has shown, "colonial science" or la colonistique, Kolonistik did not yet have the status of a discipline among the other academic disciplines with a clear definition about the areas of knowledge covered and a canon on methods and questions. Rather, many disciplines from medicine, geography, ethnography, agriculture, and botany to theology, law, and economics participated in the academic discourses on colonialism and the colonies. On the other hand, promoters of the idea of colonization of foreign territories were adamant to prove that the mise en valeur of the colonies required "colonial sciences." Thus, Wissenschaftlichkeit as a methodical approach to the colonies was-most of all-a cultural code that granted legitimacy to colonial policies around the world. ${ }^{49}$

It has recently been argued that "German imperialists ranked amongst the most ardent advocates of the use of science and technology in the systematic development of the colonies, not least because of Germany's belatedness as an imperial power." 50 In view of this self-perceived "belatedness," German administrators eagerly attempted to, sooner rather than later, reach the same stage of colonial development as France and most

${ }^{47}$ G.B. Masefield, A History of the Colonial Agricultural Service (Oxford: Oxford University Press, 1972), 117, 132.

${ }^{48}$ Sir Charles Bruce, "Tropical Medicine as Instrument of Empire," Journal of Tropical Medicine and Hygiene 11 (1908): 334; but cf. Herbert Lewis, In Defense of Anthropology: An Investigation of the Critique of Anthropology (New Brunswick, NJ: Transaction Publishers, 2014), 99f.

${ }^{49}$ Kwaschik, Der Griff nach dem Weltwissen, 29, 31, 39.

${ }^{50}$ Robrecht Declerq, "Building Imperial Frontiers: Business, Science and Karakul Sheep Farming in (German) South-West Africa (1903-1939)," Journal of Modern European History 14 (2016): 54-77, 55. 
of all Great Britain. The German willingness to learn from the "methods" and past and present experiences in foreign colonies, whether through reports or on-site visits, is most evident in German colonial files. ${ }^{51}$ Given the lack of economic alternatives and the ideas by German colonial enthusiasts to develop colonies into agrarian anti-modern refuges, agriculture as a way of life and as a knowledge system always played an important part in these debates. This can also be seen in the "colonial programme" of the colonial secretary Bernhard Dernburg (in office from 1906 to 1910). In 1907, after the genocidal wars in GSWA that led to the decimation of the labor force and the financial disaster German colonialism had caused over the last 20 years, he aimed at putting a greater emphasis on the "rational" exploitation of the riches of the colonies. In his "colonial programme," he combined economic and civilizational narratives. The colonial goal was, he argued, the "utilization of the soil, its riches, of the flora and fauna and most of all of the people for the benefit of the economy of the colonizing nation." The latter in turn was obliged to the "counter-present [Gegengabe] of its higher culture, its moral ideas, its better methods." 52

At the time the colonial secretary set these goals, the "utilization of the soil" was an accepted research and teaching subject in German universities. In German territories, literature on agriculture, horticulture, and silviculture was well established by the sixteenth century and fulfilled mostly practical requirements proprietors and managers had in terms of enhancing their returns from estates. ${ }^{53}$ In 1863, one of the first German chairs of agriculture (Professor Julius Kühn) had been institutionalized at the University of Halle. Thirty years later, Ferdinand Wohltmann, a professor of agriculture in Bonn began his study excursions to the German colonies. Due to his publications he became recognized as Germany's leading expert on tropical agriculture. Wohltmann intended to impress upon his readers the "national importance" of research in (tropical) agricultural questions and was elected a member of the board of the

${ }^{51}$ See Ulrike Lindner, Koloniale Begegnungen: Deutschland und Großbritannien als Imperialmächte in Afrika 1880-1914 (Frankfurt/M.: Campus, 2011); Dirk van Laak, "Kolonien als 'Laboratorien der Moderne'?" in Das Kaiserreich transnational: Deutschland in der Welt 1871-1914, ed. by Sebastian Conrad and Jürgen Osterhammel (Göttingen: V\&R, 2004), 257-279, 257.

${ }^{52}$ Bernhard Dernburg, Zielpunkte des deutschen Kolonialwesens (Berlin: Mittler, 1907), 5.

${ }^{53}$ Gertrud Schröder-Lembke, Studien zur Agrargeschichte (Stuttgart: Lucius, 1977), 81. 
Deutsche Kolonialgesellschaft in 1897. From 1900, he edited jointly with Otto Warburg (1859-1938) the journal Der Tropenpflanzer, which reported regularly on agricultural "progress" in all the German colonies. ${ }^{54}$ Following his transfer to the University of Halle in 1905, Wohltmann took the opportunity to set up (in 1908) and head the "Halle colonial academy," with the purpose of supporting the colonial administration with its research and teaching in tropical agriculture. ${ }^{55}$

After 1900, the research topic of "tropical agriculture" developed into an academic subject taught at a number of German universities. Similar to "colonial geography," with its practical relevance for the "development" of Germany's colonial empire, "colonial and tropical agriculture" became a research topic for which qualification theses could be written, namely German promotion and habilitation qualifications. The agriculturalist Arthur Golf was one of the first German academics who, having defended in 1903 his dissertation on agricultural irrigation in North America, ${ }^{56}$ specialized from the very beginning of his career in colonial agriculture. An academic pupil of Wohltmann, in 1907 he obtained his habilitation for colonial and tropical agriculture. Also in 1907, Golf traveled on the request of the colonial secretary to South Africa and GSWA to undertake research on the improvement of farming methods under arid conditions. ${ }^{57}$ Similar to their British counterparts, German (agricultural) scientists saw "Africa as a living laboratory," as historian Hellen Tilley argues, examining African soils and plants with modern methods, but at the same time trying to give credit to local systems of knowledge, for example, by researching the pharmaceutical value of "plants of the Herero and Hottentotts." 58 Given the fact that there were few specialists in the field, in 1912 the University of Leipzig installed the first and only extraordinary chair of tropical and colonial agriculture.

54 “Aus deutschen Kolonien," Der Tropenpflanzer (1901), 90f.; Otto Warburg, "Die wirtschaftliche Entwicklung unserer Schutzgebiete im Jahre 1903," Der Tropenpflanzer 8. Jg (1904), 14.

${ }^{55}$ Arthur Golf, Zu Ferdinand Wobltmanns Gedächtnis (Leipzig, 1919).

${ }^{56}$ Arthur Golf, Untersuchungen über die natürlichen Grundlagen der nordamerikanischen Bewässerungswirtschaft, Ph.D. diss., University of Halle, 1903.

${ }^{57}$ Arthur Golf, Ackerbau in Deutsch-Südwestafrika: Das Trockenfarmen und seine Anwendung in D.S.W.A. (Berlin: Süsserott, 1911) (Koloniale Abhandlungen no. 47/50).

${ }^{58}$ Tilley, Africa as a Living Laboratory, 127; NAN ZBU 1013 J.XIII. c. 1-2 Botanische Forschungen, Hellwig: Angaben von Eingeborenen über die Feldkost und Arzneipflanzen, June 1907. 
Golf was, thanks to his mentor Ferdinand Wohltmann, successful in his bid for this position and became a professor in Leipzig. Golf's teaching before the war centered mostly on farming agriculture as he had experienced it in GSWA.

The authorities in GSWA were well aware of the opportunities "modern science" provided for the agricultural sector of the colony. Most of all the "traumatic experience of the rinderpest epidemic had triggered the improvement and professionalization of veterinary science and services." 59 It had become clear that even those men who had succeeded in becoming good farmers were helpless before the onslaught of a hitherto incurable disease. State invention for their protection seemed thus without alternative and came in addition to massive state investment in water drilling and dam building. In 1899 the governorate in Windhoek installed its own veterinary administration in addition to the departments of agriculture and land surveying. ${ }^{60}$ In doing so, the German colonial administration was even ahead of its British counterparts in most British colonies and protectorates, where departments of agriculture were mostly institutionalized between 1902 and 1912. ${ }^{61}$

By 1911 the government's care for economic actors related to all forms of agriculture, which had developed into a sophisticated administration: seven sub-departments (Referate) were tasked with questions related to farming, veterinarian services, and water exploration. ${ }^{62}$ The veterinary service in GSWA, for a long time headed by Oberveterinär Wilhelm Rickmann, consisted of 17 veterinarians. Furthermore, from 1898 the bacteriological institute in Gammams, near Windhoek, undertook research into the causes of animal diseases and means to prevent their spread. Also, the colonial police force, established in 1907 was tasked with not only controlling the trade in livestock but also, after receiving training, as economic actors in their own right. In addition to their duty to control and closely watch the African workforce, policemen

\footnotetext{
${ }^{59}$ Giorgio Miescher, "Facing Barbarians: A Narrative of Spatial Segregation in Namibia," Journal of Southern African Studies 38 (2012): 769-786, 774.

60 "Referate des Gouvernements" (... Ref. VIII Veterinärwesen, Viehzucht (Rossarzt Rickmann); Ref. IX Landwirtschaft, Wasseranlagen, Meteorologie (Watermeyer); Ref. X Landvermessung. Landesaufnahme (Görgens)), "Decree of June 1899," reprinted in Windhoeker Anzeiger No. 29, 9.11.1899, 2.

${ }^{61}$ Masefield, A History of the Colonial, 33; Tilley, Africa as a Living Laboratory, 124.

${ }^{62}$ BAB R 1002/47, 20, 23, Geschäftsverteilungsplan Gouvernement, 2 June 1911.
} 
were given basic veterinary education in order to be able to protect cattle from diseases by controlling animals and their movement. They were given specific legal competences by the governorate concerning quarantine; yet the "veterinary service was able to fulfil these goals [of animal health] only in part." 63 Nevertheless, by 1914, it is estimated that livestock numbered at least 1.2 million animals in farm areas (within the "police zone") of GSWA (mainly goats, cattle, and sheep). ${ }^{64}$ In the words of historian Giorgio Miescher these veterinary projects need to be understood "as representations of state intervention and as specific examples of the modernization of agriculture and livestock farming. In both these instances, scientific arguments assumed increasing importance. ${ }^{\prime 65}$

\section{“Germany Has the Education and not the Colonies." The Deutsche Kolonialschule für LandWirtschaft and the Colonial Women's School}

Education (Erziehung) was a theme and a trope regularly applied in German colonial discourses. Early on in the debate the "necessity of a specific professional training of the colonial officials... generally already in the mother country" was perceived. ${ }^{66}$ Given the recurring accusations that German (colonial) officials acted rather naively with regard to economic questions, in 1892 a member of the colonial council, an (economic) advisory body to the colonial department, suggested that Germany's colonial service should be based on commercial and agricultural training. The council, however, did not support this proposal. ${ }^{67}$

Founded in 1887,2 years after the formal declaration of German sovereignty overseas, the Berlin "Seminar for Oriental Languages" (Seminar für Orientalische Sprachen) was most of all meant to improve the communication abilities of tradesmen and colonial administrators. ${ }^{68}$

${ }^{63}$ Miescher, Namibia's Red Line, 58, 86.

${ }^{64}$ Werner, "No One Will Become Rich," 63.

${ }^{65}$ Miescher, Namibia's Red Line, 200.

${ }^{66}$ Max Beneke, Die Ausbildung der Kolonialbeamten (Berlin: Heymann, 1894), v.

${ }^{67}$ B. v. König, "Die Beamten der deutschen Schutzgebiete, ihre Rechtsverhältnisse, Bezüge und Auswahl," Jahrbuch der internationalen Vereinigung für vergleichende Rechtswissenschaft und Volkswirtschaftslehre 8 (1905): 217-257, 251.

${ }^{68}$ Beneke, Die Ausbildung der Kolonialbeamten, 74; R. Ehrenberg, "Zur wirtschaftlichen Vorbildung höherer deutscher Kolonialbeamter," Beiträge zur Kolonialpolitik und Kolonialwirtschaft 1 (1899/1900): 97-98. 
Following criticism from the colonial council and press, after 1893 the areas of meteorology, trade policy, "tropical hygiene," and "tropical agriculture" were added. ${ }^{69}$

Apart from this "department of Colonial studies," more and more universities all over Germany added subjects they considered to be of "colonial relevance" to their curricula. In 1908, the Kolonialinstitut was founded in Hamburg as a central academic institution for colonial questions. ${ }^{70}$ However, as the bankruptcy of many farmers in GSWA illustrated, private individuals without academic qualification who were willing to set up businesses in the colonies needed specific knowledge too, not only capital. Already in the proto-colonial era, German businessmen dealing with agricultural products from Africa noted with remorse that in "Germany currently [1879] the number of people who know something about tropical plantations is still very small." 71

But whereas the Reich administration chose to intervene in the training of colonial officials - also in light of reoccurring colonial scandals due to the ruthless behavior of colonial officials like Carl Peters in East Africa-improvement in the education of settlers was left to private initiative. It was only in 1898, thus more than 10 years after the founding of the Seminar für Orientalische Sprachen, that colonial enthusiasts around the Lutheran pastor Ernst Albert Fabarius (1859-1927), politicians of the conservative Deutschnationale party, merchants and industrialists especially from the Rhineland, and nobility the likes of Duke Johann Albrecht zu Mecklenburg (president of the DKG) came together in order to set up an institution that could alleviate the long-felt problem of the lack of preparation of German settlers. The group envisioned a school for prospective settlers, where essential and practical up-to-date agricultural knowledge about, and for, the German colonies (but also

\footnotetext{
${ }^{69}$ Karl Gareis, Deutsches Kolonialrecht (Giessen: Roth, 1902), 42; see Marc Grohmann, Exotische Verfassung: Die Kompetenzen des Reichstags für die deutschen Kolonien in Gesetzgebung und Staatsrechtswissenschaft des Kaiserreichs (1884-1914) (Tübingen: Mohr, 2001), 264; Stephan Besser, "Die Organisation des kolonialen Wissens," in Mit Deutschland um die Welt: Eine Kulturgeschichte des Fremden in der Kolonialzeit, ed. by Alexander Honold and Klaus R. Scherpe (Stuttgart: Metzler, 2004), 272-279, 274.

${ }^{70}$ Kwaschik, Der Griff nach dem Weltwissen, 70. See Jens Ruppenthal, Kolonialismus als "Wissenschaft und Technik:" Das Hamburgische Kolonialinstitut 1908 bis 1919 (Stuttgart: Steiner, 2007).
}

${ }^{71}$ Wilhelm Hübbe-Schleiden, Ethiopien, Studien über West-Afrika (Hamburg: Friederichsen, 1879), 238. 
other overseas territories) could be collected and disseminated. By creating colonial experts in their field, it would be possible to "save part of the time of apprenticeship overseas"-a time that hitherto cost dearly to those settlers who arrived in the colonies unprepared. ${ }^{72}$ By this logic, it seemed more promising to obtain in Europe the education needed for the training of competent economic actors and thus for the development of colonial Africa. ${ }^{73}$ Similar to the British case, German colonial enthusiasts believed in the "triumph of experts" and their "agrarian doctrines of development" for the colonies. ${ }^{74}$

In May 1898 the Deutsche Kolonialschule für Landwirtschaft, Handel und Gewerbe Wilhelmshof (DKS) in Witzenhausen (northern Hesse) was founded as a private enterprise $(G m b H)$, but with the moral and continuing financial support of the colonial administration in Berlin. The DKS provided a concrete example for actors and institutions involved in shaping the link between education and "development" in German colonial Africa. This initiative was part of a "wave of foundations of [colonial] institutes in Europe" around 1900. ${ }^{75}$ The school board, including the agriculturalist professor Wohltmann, viewed (colonial) agricultural education as a means not only to make the German colonies economically more viable through the application of "modern," "scientific" methods, but also as a means to spread the kolonialer Gedanke in Germany. ${ }^{76}$

Also, the DKS was a prime example of how international and imperial discourses on the agricultural mise en valeur of the colonies led to concrete attempts to copy best-practice examples from one colonial power to another. For the German case such transnational and inter-imperial entanglements have been investigated, most of all for the German cotton industry in Togo. ${ }^{77}$ But the inter-imperial circulations of knowledge also

${ }^{72}$ Article "Witzenhausen," in Deutsches Kolonial-Lexikon, vol. III (Leipzig, 1920), $723 f$.

${ }^{73}$ Kwaschik, Der Griff nach dem Weltwissen, 70.

${ }^{74}$ Joseph Hodge, Triumph of the Expert: Agrarian Doctrines of Developments and the Legacies of British Colonialism (Athens: Ohio University Press, 2007).

${ }^{75}$ Kwaschik, Der Griff nach dem Weltwissen, 49; Jens Böhlke, Zur Geschichte der Deutschen Kolonialschule in Witzenhausen: Aspekte ibres Entstebens und Wirkens (Witzenhausen: Werratalverein, 1995), 96.

${ }^{76}$ Karsten Linne, Von Witzenhausen in die Welt: Ausbildung und Arbeit von Tropenlandwirten 1898 bis 1971 (Göttingen: Wallstein, 2017), 25-35.

${ }^{77}$ Andrew Zimmerman, Alabama in Africa: Booker T. Washington, the German Empire, and the Globalization of the New South (Princeton: Princeton University Press, 2010). 
concerned the history of education-both in and about Africa. Like the academic colonial institutions set up around 1900 in Germany, in a similar manner to the DKS, the German colonial "late-comers" were willing to look west and learn from the more seasoned colonial powers. ${ }^{78}$ Fabarius considered as most relevant the British Colonial college and training farms in Harwich and the Dutch Rijkslandbouwschool (National Agricultural College), already established in 1876 in Wageningen.

In turn, it was seen by Germans with satisfaction that the "colonial school" in Nantes, France, was allegedly "modeled exactly after the plan of the German colonial school" in Witzenhausen. ${ }^{79}$ The first edition of the DKS's own publication Der deutsche Kulturpionier (1900) quoted with pride an unnamed French newspaper that had characterized the DKS as "l'institut colonial le plus complet!" 80 In 1911, the British journalist Louis Hamilton, who worked in Berlin as an English teacher at the Seminar for Oriental Languages, commented: "the Colonial School of Witzenhausen ... is in reality preeminently an agricultural college ... What is evident is that in education of the better class of colonists Germany is ahead of all countries, as she always is in matters educational. If we Britishers, with our vast Empire, would only remember what our own opportunities for Colonial education are, we might begin to turn over a new leaf. ... Germany has the education and not the Colonies; we have the Colonies and not the education." 81

The DKS offered to educate and practically train future plantation officials, as well as farmers, livestock farmers, or wine and fruit farmers for the German colonies and other settlement areas in the (sub)tropics. For such settlements, the DKS welcomed German nationals aged between 17 and 27 years of age on training courses lasting between 2 and 3 years. Fabarius remained eager in emphasizing the "academic character" (Hochschulcharakter) of the DKS. There were, however, no formal secondary education requirements for admittance to the DKS. It was a

\footnotetext{
${ }^{78}$ See Jakob Zollmann, "German Colonial Law and Comparative Law, 1884-1919," in Entanglements in Legal History: Conceptual Approaches, ed. by Thomas Duve (Frankfurt/M.: MPI, 2014), 253-294.

${ }^{79}$ Article "Kolonialschulen," in Meyers Großes Konversations-Lexikon, vol. 11 (Leipzig, 1907), 290.

80 “Ausländische Kolonialschulen," Der deutsche Kulturpionier 1, no. 1 (1900): 40.

${ }^{81}$ Cited in Böhlke, Zur Geschichte der Deutschen Kolonialschule, 95; see Besser, "Die Organisation," 274.
} 
tenet of Fabarius to jointly consider practice and theory in the school's efforts to impart knowledge about (colonial) agriculture. This policyFabarius spoke of "colonial pedagogics"-resulted in an immense curriculum (laid out over 6 days a week from 7:15 a.m. to 6 p.m.) that all too often demanded too much of students. The subjects taught were grouped into "general," "agriculture," "tropical," "practical works," and "physical exercises," 82 topics, thus:

The "course list" of the summer term 1900 included the following courses:

I. General: 1. Ethnology, 2. History of Religion, 3. Organic Chemistry, 4. General Botany and Plant Physiology, 5. Practical Geology, 6. Veterinary Medicine, 7. Tropical Medicine, 8. Economics with special reference to the colonial economy.

II. Agriculture: 1. Crop production, 2. Vegetables, Horticulture, and Viticulture, 3. Land Surveying, 4. Forestry, 5. Civil Engineering (bridge construction, road construction, irrigation and drainage).

III. Tropical: 1. Planting and operating plantations, 2. Tropical fruits and vegetables, 3. Tropical domestic animals and steppe farming.

IV. Practical work: 1. Forge, 2. Locksmithery, 3. Wagon construction, 4. Carpentry, 5. Timber framing [Zimmerei], 6. Saddlery, 7. Boatbuilding, 8. Fishing.

V. Physical exercises: gymnastics and fencing, horse riding, shooting.

VI. Participation in private lessons in foreign languages "is not compulsory for all students." 83

In Witzenhausen, physical exercises and horse riding were perceived as an important part of the general education of future colonialists. In this respect, the curricula of the DKS were closer to those in British and French institutions than to their German academic counterparts in Berlin and Hamburg. The belief was widespread that virile and hardy characters were a prerequisite for a successful colonial career. And it was equally

\footnotetext{
${ }^{82}$ Böhlke, Zur Geschichte der Deutschen Kolonialschule, 81; Linne, Von Witzenhausen, 37.

83 "Vorlesungs- und Unterrichtsverzeichnis für das Sommerhalbjahr 1900," Der deutsche Kulturpionier 1, no. 1 (1900): 1.
} 
assumed that such characters were necessarily formed through (hard) exercise. Behind this emphasis on "character formation" and "corporeality" was, as historian Anne Kwaschik points out, more than the intention to secure the work capability of settlers. There was an anthropological dimension in the debates about the vocational training of (future) colonialists, which perceived the hardy man needed in the colonies as an "antitype to the modern urban-civilized man." 84 In the age of widespread criticism of civilization, the colonies were thus imagined as spaces that could — on an individual basis—-help to renew, improve, and "rejuvenate" metropolitan societies.

Given the ideals connected to his institution, Fabarius, a towering figure and authoritarian character, was convinced that the German colonies required the "noblest, most reliable and best sons of our people." He expected that the sons of the "most competent classes of our nation, in particular [the sons] of agronomists, civil servants, doctors, merchants, and officers" would apply to join the DKS. Evidently, these demands stood in sharp contrast to the "image" widespread in Germany "of a debased settler population [in GSWA] prone to violence, alcoholism, and crime." 85 Apparently, according to tables giving an overview of the parents of DKS students, most were indeed from a middle-class background. The average age of admitted students was 19-20 years with some having already been conscripted to military service. ${ }^{86}$ The school was organized in the spirit of a German cadet school. Fabarius required of his students a "German national attitude" (deutsch nationale Gesinnung) and applied a militaristic code of conduct for all students. Similar to what school children experienced in Wilhelminian schools ${ }^{87}$ the strictest discipline was enforced with the aim to educate "self-discipline," a trait that was assumed necessary to farm in the colonies. Between 1898 and 1918 some 779 students joined the DKS, but only $60 \%$ of them received an official diploma from the school. ${ }^{88}$

Much to the chagrin of the directorate, by 1910 less than half the DKS graduates had settled in German colonies. The territory that

\footnotetext{
${ }^{84}$ Kwaschik, Der Griff nach dem Weltwissen, 86f.

${ }^{85}$ Short, Magic Lantern Empire, 71.

${ }^{86}$ Böhlke, Zur Geschichte der Deutschen Kolonialschule, $91 \mathrm{f}$.

${ }^{87}$ See York-Gothart Mix, Die Schulen der Nation: Bildungskritik in der Literatur der frühen Moderne (Stuttgart: Metzler, 1995), $217 \mathrm{f}$.

${ }^{88}$ Böhlke, Zur Geschichte der Deutschen Kolonialschule, 93.
} 
welcomed the largest group of DKS graduates before World War I was GSWA (133), followed by GEA (88), Nigeria (32), Argentina and Canada (25 each), the United States (23), and German New Guinea (18). Thus, the majority did indeed settle in Africa, but Fabarius was concerned that education offered at the DKS served merely as a "cultural fertilizer" for other colonial powers. ${ }^{89}$

The education and work undertaken at the DKS was a strictly male affair. Women were not admitted. In 1907, however, plans were made in Witzenhausen to open a colonial women's school (Kolonialfrauenschule) as a partner institution in the neighborhood. ${ }^{90}$ From the 1890 s, colonial enthusiasts were convinced of the relevance of women in Germany's colonial endeavors. In their writings they created "the colonial women's question," which was to be solved by bringing more German women to the colonies. Over the last decades, historians have repeatedly shown how the colonial administration, colonial pressure groups like the DKG, as well as women's movements cooperated to settle more German women in the German colonies (most of all GSWA) and thereby assumed to protect and maintain the Deutschtum (Germandom) overseas. In the debates about women in the colonies, discourses on race, class, gender, feminism, nationalism, colonialism, and education partly merged, as the "right" women (but only those women, not members of the "lower classes") were imagined as Kulturträgerinnen, as bearers of (German) culture. ${ }^{91}$ The goal of a more "civilised" environment on a private and public level, it was argued, would have remained unattainable without female support and female "abilities" to create, through their "domesticity," a German home with German (white) children; a German Heimat - and thus prevent "the German men" from "going native" by

${ }^{89}$ Map, Ausreiseziele 1899-1914, reproduced in Böhlke, Zur Geschichte, 90; Linne, Von Witzenhausen, 77, 79 .

${ }^{90}$ Dörte Lerp, "Zwischen Bevölkerungspolitik und Frauenbildung, Die Kolonialfrauenschulen in Witzenhausen und Bad Weilbach," in Frawen in den deutschen Kolonien, ed. by Marianne Bechhaus-Gerst and Mechthild Leutner (Berlin: Links, 2009), $32-39,32$.

${ }^{91}$ Katharina Walgenbach, "Die weiße Frau als Trägerin deutscher Kultur". Koloniale Diskurse über Geschlecht, "Rasse" und Klasse im Kaiserreich (Frankfurt/M.: Campus, 2005); Krista O’Donnell, "Home, Nation, Empire: Domestic Germanness and Colonial Citizenship," in The Heimat Abroad: The Boundaries of Germanness, ed. by Krista O'Donnell, Renate Bridenthal, and Nancy Reagin (Ann Arbor: University of Michigan Press, 2005), 40-57; Kundrus, Moderne Imperialisten. 
living with "native women," resulting in racial "degeneration." Such biopolitical argumentation about "mothers for the state" conformed to contemporary women's rights activists' parlance about "specific female qualities" or "motherly abilities." These were to be supported and provided for the greater good and in the interest of the nation-be it, for example, through better education of young women or the recognition of the societal relevance of motherhood. ${ }^{92}$

The colonial women's school in Witzenhausen was initiated by the DKG, the DKS, the Deutsch-Evangelische Franenbund, the Association for Women's Education, the Deutsche Franenverein für Krankenpflege in den Kolonien, and further individuals including Empress Auguste Victoria-their purpose being to convince more unmarried, gebildete, that is, women of bourgeois respectability, not only to go to the (German) colonies, but to seek special education before doing so. The school was supposed to prepare students for roles in the colonies as teachers, kindergarten teachers, and nurses, but primarily as farmers' wives, who were-apart from managing a "German" household (cooking, cleaning, childcare)—well versed in tasks such as gardening, carpentry, or poultry farming. Director Fabarius always remained involved in the development of curricula for the colonial women's school and was eager to make it more or less a dependency of "his" DKS.93

The first four female students enrolled in May 1908 on a 1-year course, but in 1910 the number had barely risen to 13. Initially, under the directorship of Helene von Falkenhausen (a teacher who had been a trader's/farmer's wife in GSWA ${ }^{94}$ ) and, from 1909, Anna von Zech, young women had to study, in addition to housekeeping, most of the courses their male colleagues at the DKS took, such as natural sciences, tropical agriculture, and health. Considering the very low enrollment numbers, Fabarius admitted that the offers made by the women's school seemed to be unattractive to young women. When Helene von Falkenhausen quit as director, her successor Anna von Zech, however, insisted on the overloaded curriculum, since only this would enable her students to acquire an education "which corresponds to that of the

\footnotetext{
${ }^{92}$ Short, Magic Lantern, 72f.; Sylvia Schraut, Bürgerinnen im Kaiserreich: Biografie eines Lebensstils (Stuttgart: Kohlhammer, 2013), 115.

${ }^{93}$ Lerp, "Zwischen Bevölkerungspolitik und Frauenbildung," $33 \mathrm{f}$.

${ }^{94}$ Helene von Falkenhausen, Ansiedler-Schicksale: Elf Jahre in Deutsch-Südwestafrika 1893-1904 (Berlin: Reimer, 1906).
} 
young men." Considering wives as "comrades" of their husbands, von Zech aimed to enable her students to "deputize" (vertreten) for their (future) husbands in terms of running a farm. Thus, she wanted her students to be good "German" wives and good farmers at the same time. Such an understanding of comaraderie and equality between women and men in the colonies was, however, not the educational ideal of Fabarius. Continuing disputes with Fabarius alongside protests from female students against the overloaded curriculum, financial difficulties, and the very small number of students finally led, in August 1910, to the colonial women's school closing. A few months later, however, the same organizers of Witzenhausen attached a new colonial women's school to the already existing women's economic school in Bad Weilbach near Wiesbaden. Between 1911 and 1915 around 40 female students enrolled on the "colonial courses." It is known that five of them indeed migrated to GSWA or East Africa. It is also known that many settlers rejected the "well-educated," "bourgeois" women whom they deemed as too demanding and "less resilient" in comparison to lower class women from Germany. Given this dispute about the "right" women for the colonies and the prejudices against educated women, despite support from the DKG, the colonial women's school did not always succeed in finding graduates an appropriate position in GSWA or elsewhere. ${ }^{95}$ However, male experts also experienced a bias of farmers in GSWA away from academic expertise. After one agricultural expert had traveled in GSWA he complained to a high-ranking administrator: "everyone comes to see me, except for the farmers. They know everything better ...." 96 This aversion of some settlers in GSWA against formal education became even more evident in respect to their African workforce.

\section{Educating Africans as Workers? Why or Why Not?}

In his classic Portrait du colonisé (1957), the Tunisian sociologist Albert Memmi commences his chapter on the "mythical portrait of the colonized" with a consideration of the colonial image of the "often cited trait of laziness." This image of the "unbelievable laziness" of the colonized

\footnotetext{
${ }^{95}$ Lerp, “Zwischen Bevölkerungspolitik und Frauenbildung," 32, 36, 39. Jens Böhlke, Zur Geschichte der Deutschen Kolonialschule, 59-64.

${ }^{96}$ BAB N 2272/1, Bl. 28-30, Heydebreck an Schuckmann, 9.2.1914; see Linne, Von Witzenhausen, 78 .
} 
served several purposes; not least it "justifies the colonized's destitution." Memmi also rightfully pointed out that it "may seem that colonization would profit by employing experienced personnel [i.e., educated Europeans]. Nothing is less true"-for the simple reason that in the colonies it was more advantageous to employ the colonized than colonizers: "three or four can be taken for the price of one European," whereas the European would not "produce three or four times as much" as one colonized would. ${ }^{97}$

Even 50 years earlier, in German colonial discourses the "myth of the lazy native" 98 was omnipresent. For example, during the three German Colonial Congresses held in 1902, 1905, and 1910 "discussions of race and labor ... emphasized the need to educate the Negro to work." 99 One response of the colonial administration in GSWA to the widespread complaints about the insufficiency of the African workforce in general was a wide-ranging legal package. With three "native ordinances" (1907) dealing with control measures, passes, and work contracts for all Africans, the administration in Windhoek hoped "to transform the Africans into a landless proletariat, destroy their political organization and culture, and forcing them to work in a disciplined and orderly manner for white employers." 100 The ordinances, however, also speak of the German insight that African labor was irreplaceable for German employers- the colony could not be developed without them. In fact, in GSWA the "value" of "the native" was seen most of all as being his or her ability to work for the Germans. This was also the philosophy of long-term governor Theodor Leutwein. However, beginning with the Herero war and the demotion of Leutwein by his successor General Lothar von Trotha in 1904, the necessity of Africans in this colony was increasingly in doubt. Trotha "in contrast to Leutwein saw the indigenous workforce in the settler colony as replaceable." ${ }^{101}$ Trotha did not believe in the viability of the colonial tenet - to adapt a book title-of "white farms,

\footnotetext{
${ }^{97}$ Albert Memmi, The Colonizer and the Colonized (Boston: Beacon Press, 1965), $79 f$.

${ }^{98}$ Syed H. Alatas, The Myth of the Lazy Native (London: Cass, 1977).

${ }^{99}$ Zimmerman, Alabama in Africa, 188. See Alexander Merensky, Wie erzieht man am besten den Neger zur Plantagen-Arbeit? (Berlin: Walther, 1886); Ulrike Schaper, Koloniale Verhandlungen: Gerichtsbarkeit, Verwaltung und Herrschaft in Kamerun 1884-1916 (Frankfurt/M.: Campus, 2012), 367.

${ }^{100}$ Wallace, A History of Namibia, 184.

${ }^{101}$ Häussler, Der Genozid an den Herero, 47.
} 
black labour." 102 On his vision of a "white man's country," Trotha wrote in his diary: "but SWA is, or should be, the colony where the European can work himself." 103

Even though Trotha was for some time governor of GSWA, such comments, however, never meant that there was an official German policy that aimed at a sort of colonial rule without the colonized. Yet, it is evident from sources as well as comparisons with other colonies, that in GSWA debates about "native uplift" were, if not wholly absent, muted at best. For a number of African children (mostly mission), primary schools were opened that received small government subsidies. ${ }^{104}$ Yet, illiteracy remained the norm for African children and youths. After 1907, with the end of the wars, civilizational discourses about "the natives" and their "improvement," "education," and "development" were rather transformed into debates about security. Administrators and settlers hoped for a more "docile" African populace that was "taught a lesson" by the Germans and was to be constantly reminded of its place on the lowest level of the colony's social ladder. Whereas in many African colonies, including GEA and Togo, administrators considered it "part of the state-building process" to encourage "the natives" to cultivate cash crops ${ }^{105}$ in GSWA Africans were imagined only as (farm) workers, not as independent (subsistence) agriculturalists. Still, given the relative economic insignificance of GSWA, administrators never grew tired of reminding settlers that the "native population"-through its capacity to work for the colonial economy-was the colony's most important asset. Therefore, following his genocidal warfare against the Ovaherero in 1904, Trotha was harshly criticized by other officials for having destroyed almost all the "properties" of GSWA: native workers and cattle, and thus he would "ruin" the colony. ${ }^{106}$ Most of all, for employers Africans were-as Memmi had already emphasized-much cheaper than an imported German workforce.

${ }^{102}$ Alan H. Jeeves and Jonathan Crush (eds.), White Farms, Black Labor: The State of Agrarian Change in Southern Africa, 1910-1950 (Portsmouth: Heinemann, 1997).

${ }^{103}$ Trotha diary entry of 1 July 1904, cited in Häussler, Der Genozid an den Herero, 47.

${ }^{104}$ Jakob Zollmann, "Children of Empire: Childhood, Education and Space in German South West Africa, c. 1880-1915," Journal of Namibian Studies 17 (2015): 71-124.

${ }^{105}$ Tilley, Africa as a Living Laboratory, 128.

${ }^{106}$ Rohrbach, cited in Häussler, Der Genozid an den Herero, 219. 
These employers most often fervently believed in the idea of racially inherent traits in blacks, and "education" in whatever form was seen by them as time consuming, disturbing, and creating the wrong sense of self-esteem among those Africans lucky enough to have experienced a school. Others, perversely, argued that they educated "their natives" by the whip, by teaching them "a lesson" in obedience. In the rare cases that the colonial administration, through policemen and judges, reacted to these violent excesses (very few farmers actually went to jail for flogging their workers), settlers complained angrily that the authorities dared to interfere with their "right" to "paternal chastisement." Arbitrariness, despotism, and violence against Africans was seen by many farmers "as an integral part of their white Herrenanspruch." 107 They rejected any state inference with what they conceived as their "education." After all, the journal Kulturpionier from Witzenhauses had declared "that every colonial employer is first of all an educator," teaching "natives" how to work. ${ }^{108}$ Additionally, academics never grew tired of emphasizing that "the native must be treated like a child and a certain force is thus necessary." 109

The very harsh treatment of African workers by some German farmers led farm workers regularly to the decision to flee their farms rather than endure further hardship. "These Africans living on the veld occasionally raided European farms, stealing cattle for food or slaughtering the animals in revenge." 110 Such events were used as self-fulfilling prophecies seemingly proving that "the native" was unwilling or even incapable of serious labor. How could Africans be compelled to work- especially for (settler) farmers? This question had, since the beginning of the abolition of slavery in the United States (1865) and Brazil (1888), a distinctive transatlantic dimension and German academics and farmers participated in this transnational debate alike. ${ }^{111}$

${ }^{107}$ Häussler, Der Genozid an den Herero, 52.

108 "Die Völkerkunde und Kolonialwirtschaft," Der deutsche Kulturpionier 1, no. 3 (1900): $46 f$.

${ }^{109}$ Bernhard Dernburg, Zielpunkte des deutschen Kolonialwesens (Berlin: Mittler, 1907), 61 (Anlage 1 Bericht des Prof. Dr. Hahn und des Farmers Schlettwein in der Kommission für den Reichshaushalts-Etat am 12. Dezember 1906).

${ }^{110}$ Miescher, Namibia's Red Line, 63.

${ }^{111}$ Bradley Naranch, "Global Proletarians, Uncle Toms, and Native Savages: Popular German Race Science in the Emancipation Era," in Germany and the Black Diaspora: Points of Contact, 1250-1914, ed. by Mischa Honeck, Martin Klimke, and Anne Kuhlmann, 169-186, 17lf. 
Ferdinand Wohltmann pleaded: "Without a duty to work [for Africans] a development of culture ... is impossible." 112

Vocational training and other educational policies for Africans differed widely between German colonies. In Cameroon, private companies, for example, construction firms, were prepared to send African apprentices for further instruction to Germany. ${ }^{113}$ However, in comparison with German Togo and a number of British colonies, in GSWA, agricultural education and practical training for African children and young adults was not on the agenda of government institutions. One reason for this decision not to act was certainly the fact that, much to the surprise of German settlers and administrators, in "the years after 1907, Africans were also taking whatever opportunity they could find to regenerate the herds they had lost." Herero agricultural knowledge and their own forms of educating a new generation of pastoralists sufficed in establishing new cattle herds. "By 1913, Ovaherero owned more than 25 percent of the small stock in the colony, as well as more than twenty thousand head of large stock."114 Thus, the German settlers had ample reason to fear competition and they "lobbied for protection from [it]."115 Any sort of broader education would have further strengthened the position of the Africans. In German mission schools, however, the management of a school garden was at times part of the curriculum for African children. ${ }^{116}$ Whereas in neighboring South Africa "agricultural education gained momentum" in the early 1900s, for example, in the Transkei, with

112 "Die Beamten- und Arbeiterfrage in unseren Kolonien von Geh. Rat Prof. Dr. Wohltmann," in Der deutsche Kulturpionier 2, no. 3 (1901): 54. Cf. Christel Adick and Wolfgang Mehnert (eds.), Deutsche Missions- und Kolonialpädagogik in Dokumenten. Eine kommentierte Quellensammlung aus den Afrikabeständen deutschsprachiger Archive 1884-1914 (Frankfurt/M: IKO, 2001), 337.

${ }^{113}$ Robbie Aitken, "Education and Migration: Cameroonian Schoolchildren and Apprentices in Germany, 1884-1914," in Germany and the Black Diaspora, ed. by Honeck, Klimke and Kuhlmannp, 213-230, 217f.

${ }^{114}$ Wallace, A History of Namibia, 184.

${ }^{115}$ Cynthia Cohen, “'The Natives Must First Become Good Workmen': Formal Educational Provisions in German South West and East Africa Compared," Journal of Southern African Studies 19 (1993): 115-134, 129.

${ }^{116}$ Adick, Kolonialpädagogik, 338. 
"chiefs, headmen, and progressive [African] farmers ... actively engaged with the idea of 'scientific agriculture', [and] invested in machinery and better stock," 117 in GSWA the political goals concerning the education of Africans remained bound by notions of obedience and unfree labor in the service of Germans.

This is a stark reminder that a history of education must also consider and analyze the reasons for an active denial of an education (and development) for certain groups enabling the profit of others.

\section{BIBLIOGRAPHY}

Adick, Christel, and Wolfgang Mehnert, eds. Deutsche Missions- und Kolonialpädagogik in Dokumenten. Eine kommentierte Quellensammlung aus den Afrikabeständen deutschsprachiger Archive 1884-1914. Frankfurt/M: IKO, 2001.

Aitken, Robbie. "Looking for Die Besten Boeren: The Normalisation of Afrikaner Settlement in German South West Africa, 1884-1914." Journal of Southern African Studies 33, no. 2 (2007): 343-360.

- "Education and Migration: Cameroonian Schoolchildren and Apprentices in Germany, 1884-1914." In Germany and the Black Diaspora: Points of Contact, 1250-1914, edited by Mischa Honeck, Martin Klimke, and Anne Kuhlmann, 213-230. New York: Berghahn, 2013.

Alatas, Syed H. The Myth of the Lazy Native. London: Cass, 1977.

Bechhaus-Gerst, Marianne, and Reinhard Klein-Arendt, eds. Die (koloniale) Begegnung: AfrikanerInnen in Deutschland und schwarze Deutsche. Frankfurt/M.: P. Lang, 2004.

Besser, Stephan. "Die Organisation des kolonialen Wissens." In Mit Deutschland um die Welt: Eine Kulturgeschichte des Fremden in der Kolonialzeit, edited by Alexander Honold and Klaus R. Scherpe, 272-279. Stuttgart: Metzler, 2004.

Bley, Helmut. Kolonialherrschaft und Sozialstruktur in Südwestafrika. Hamburg: Leibnitz, 1968.

Böhlke, Jens. Zur Geschichte der Deutschen Kolonialschule in Witzenhausen: Aspekte ibres Entstehens und Wirkens. Witzenhausen: Werratalverein, 1995.

Bundy, Colin. The Rise and Fall of the South African Peasantry. London: Currey, 1979.

${ }^{117}$ Julia Tischler, "Education and the Agrarian Question in South Africa, c. 1900-40," Journal of African History 57 (2016): 251-270, 254f.; see Masefield, History of Colonial Agricultural Service, $117 \mathrm{f}$. 
Cohen, Cynthia. “'The Natives Must First Become Good Workmen': Formal Educational Provisions in German South West and East Africa Compared." Journal of Southern African Studies 19 (1993): 115-134.

Conrad, Sebastian. Globalisierung und Nation im deutschen Kaiserreich. Munich: Beck, 2006.

Declerq, Robrecht. "Building Imperial Frontiers: Business, Science and Karakul Sheep Farming in (German) South-West Africa (1903-1939)." Journal of Modern European History 14 (2016): 54-77.

Denzel, Markus. "Die wirtschaftliche Bilanz des deutschen Kolonialreiches." In Die Deutschen und ihre Kolonien: Ein Überblick, edited by Horst Gründer and Hermann Hiery, 144-160. Berlin: Bebra, 2017.

Echenberg, Myron. “'Scientific Gold': Robert Koch and Africa, 1883-1906." In Agency and Action in Colonial Africa, 34-49. London, 2001.

Eckl, Andreas. "'Weiß oder Schwarz?" Kolonialer Farmalltag in DeutschSüdwestafrika." In Die (koloniale) Begegnung: AfrikanerInnen in Deutschland und schwarze Deutsche, edited by Marianne Bechhaus-Gerst and Reinhard Klein-Arendt, 109-124. Frankfurt/M.: P. Lang, 2003.

Emmett, Tony. Popular Resistance and the Roots of Nationalism in Namibia, 1915-1966. Basel: Schlettwein, 1999.

Grohmann, Marc. Exotische Verfassung: Die Kompetenzen des Reichstags für die deutschen Kolonien in Gesetzgebung und Staatsrechtswissenschaft des Kaiserreichs (1884-1914). Tübingen: Mohr, 2001.

Groppe, Carola. Im deutschen Kaiserreich: Eine Bildungsgeschichte des Bürgertums 1871-1918. Vienna: Böhlau, 2018.

Habermas, Rebekka, and Alexandra Przyrembel. Von Käfern, Märkten und Menschen: Kolonialismus und Wissen in der Moderne. Göttingen: V\&R, 2013.

Häussler, Matthias. Der Genozid an den Herero. Weilerswist: Velbrück, 2018.

Henrichsen, Dag. Herrschaft und Alltag im vorkolonialen Zentralnamibia: Das Herero- und Damaraland im 19. Jahrbundert. Basel: BAB, 2011.

Herbert, Lewis. In Defense of Anthropology: An Investigation of the Critique of Anthropology. New Brunswick, NJ: Transaction Publishers, 2014.

Hodge, Joseph. Triumph of the Expert: Agrarian Doctrines of Developments and the Legacies of British Colonialism. Athens: Ohio University Press, 2007.

Jeeves, Alan H., and Jonathan Crush, eds. White Farms, Black Labor: The State of Agrarian Change in Southern Africa, 1910-1950. Portsmouth: Heinemann, 1997.

Kienetz, Alvin. Nineteenth-Century South West Africa as a German Settlement Colony (2 vols.), diss. phil., University of Minnesota, 1976.

Kundrus, Birte. Moderne Imperialiste: Das Kaiserreich im Spiegel seiner Kolonien. Cologne: Böhlau, 2003.

Kwaschik, Anne. Der Griff nach dem Weltwissen: Zur Genealogie von Area Studies im 19. und 20. Jahrhundert. Göttingen: V\&R, 2018. 
Laak, Dirk van. Imperiale Infrastruktur: Deutsche Planungen für Afrika. Paderborn: Schöningh, 2004.

_. "Kolonien als 'Laboratorien der Moderne'?" In Das Kaiserreich transnational: Deutschland in der Welt 1871-1914, edited by Sebastian Conrad and Jürgen Osterhammel, 257-279. Göttingen: V\&R, 2004.

Lerp, Dörte. "Zwischen Bevölkerungspolitik und Frauenbildung, Die Kolonialfrauenschulen in Witzenhausen und Bad Weilbach.” In Franen in den deutschen Kolonien, edited by Marianne Bechhaus-Gerst and Mechthild Leutner, 32-39. Berlin: Links, 2009.

Lindner, Ulrike. Koloniale Begegnungen: Deutschland und Großbritannien als Imperialmächte in Afrika 1880-1914. Frankfurt/M.: Campus, 2011.

Linne, Karsten. Von Witzenhausen in die Welt: Ausbildung und Arbeit von Tropenlandwirten 1898 bis 1971. Göttingen: Wallstein, 2017.

Marklund, Carl. "Begriffsgeschicht and Übergriffsgeschichte in the History of Social Engineerung." In Die Ordnung der Moderne: Social Engineering im 20. Jahrhundert, edited by Thomas Etzemüller, 199-222. Bielefeld, 2009.

Masefield, G.B. A History of the Colonial Agricultural Service. Oxford: Oxford University Press, 1972.

Memmi, Albert. The Colonizer and the Colonized. Boston: Beacon Press, 1965.

Miescher, Giorgio. Namibia's Red Line: The History of a Veterinary and Settlement Border. New York: Palgrave, 2012.

- "Facing Barbarians: A Narrative of Spatial Segregation in Namibia." Journal of Southern African Studies 38 (2012): 769-786.

Mix, York-Gothart. Die Schulen der Nation: Bildungskritik in der Literatur der frühen Moderne. Stuttgart: Metzler, 1995.

Namhila, Ellen Ndeshi. "Little Research Value:" African Estate Records and Colonial Gaps in a Post-colonial Archives. Basel: BAB, 2017.

Naranch, Bradley. "Global Proletarians, Uncle Toms, and Native Savages: Popular German Race Science in the Emancipation Era." In Germany and the Black Diaspora: Points of Contact, 1250-1914, edited by Mischa Honeck, Martin Klimke, and Anne Kuhlmann, 169-186. New York: Berghahn, 2013.

O'Donnell, Krista. "Home, Nation, Empire: Domestic Germanness and Colonial Citizenship." In The Heimat Abroad: The Boundaries of Germanness, edited by Krista O'Donnell, Renate Bridenthal, and Nancy Reagin, 40-57. Ann Arbor: University of Michigan Press, 2005.

Rawlinson, Johann. The Meat Industry of Namibia, 1835-1994. Windhoek: Gamsberg, 1994.

Ruppenthal, Jens. Kolonialismus als "Wissenschaft und Technik:" Das Hamburgische Kolonialinstitut 1908 bis 1919. Stuttgart: Steiner, 2007.

Schaper, Ulrike. Koloniale Verhandlungen: Gerichtsbarkeit, Verwaltung und Herrschaft in Kamerun 1884-1916. Frankfurt/M.: Campus, 2014. 
Schraut, Sylvia. Bürgerinnen im Kaiserreich: Biografie eines Lebensstils. Stuttgart: Kohlhammer, 2013.

Schröder-Lembke, Gertrud. Studien zur Agrargeschichte. Stuttgart: Lucius, 1977.

Schulze, Theodor. "Erziehung und Lernen. Plädoyer für eine mathetische Erziehungswissenschaft." In Erziehungsdiskurse, edited by Winfried Marotzki and Lothar Wigger, 29-50. Bad Heilbrunn: Klinkhardt, 2008.

Short, John Phillip. Magic Lantern Empire: Colonialism and Society in Germany. Ithaca, NY: Cornell University Press, 2012.

Tilley, Helen. Africa as a Living Laboratory: Empire, Development, and the Problem of Scientific Knowledge, 1870-1950. Chicago: University of Chicago Press, 2011.

Tischler, Julia. "Education and the Agrarian Question in South Africa, c. 19001940." Journal of African History 57 (2016): 251-270.

Walgenbach, Katharina. "Die weiße Frau als Trägerin deutscher Kultur:" Koloniale Diskurse über Geschlecht, "Rasse" und Klasse im Kaiserreich. Frankfurt/M.: Campus, 2005.

Wallace, Marion. A History of Namibia. London: Hurst, 2011.

Werner, Wolfgang. "No One Will Become Rich:" Economy and Society in the Herero Reserves in Namibia, 1915-1946. Basel: BAB, 1998.

Zimmerman, Andrew. Alabama in Africa: Booker T. Washington, the German Empire, and the Globalization of the New South. Princeton: PUP, 2010.

Zollmann, Jakob. Koloniale Herrschaft und ibre Grenzen: Die Kolonialpolizei in Deutsch-Südwestafrika. Göttingen: V\&R, 2010.

—. "German Colonial Law and Comparative Law, 1884-1919." In Entanglements in Legal History: Conceptual Approaches, edited by Thomas Duve, 253-294. Frankfurt/M.: MPI, 2014.

-. "Children of Empire: Childhood, Education and Space in German South West Africa, c. 1880-1915." Journal of Namibian Studies 17 (2015): $71-124$.

. "Neither the State Nor the Individual Goes to the Colony in Order to Make a Bad Business:' State and Private Enterprise in the Making of Commercial Law in the German Colonies, ca. 1884 to 1914." In The Influence of Colonies on Commercial Law and Practice, edited by Serge Dauchy and Albrecht Cordes. Leiden: Brill, 2020. 
Open Access This chapter is licensed under the terms of the Creative Commons Attribution 4.0 International License (http://creativecommons.org/licenses/ by $/ 4.0 /)$, which permits use, sharing, adaptation, distribution and reproduction in any medium or format, as long as you give appropriate credit to the original author(s) and the source, provide a link to the Creative Commons license and indicate if changes were made.

The images or other third party material in this chapter are included in the chapter's Creative Commons license, unless indicated otherwise in a credit line to the material. If material is not included in the chapter's Creative Commons license and your intended use is not permitted by statutory regulation or exceeds the permitted use, you will need to obtain permission directly from the copyright holder.

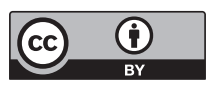

